\title{
A DNA vaccine encoding the viral hemorrhagic septicemia virus genotype IVb glycoprotein confers protection in muskellunge (Esox masquinongy), rainbow trout (Oncorhynchus mykiss), brown trout (Salmo trutta), and lake trout (Salvelinus namaycush)
}

Isaac F. Standish ${ }^{1}$, Elena V. Millard ${ }^{1}$, Travis O. Brenden ${ }^{2}$ and Mohamed Faisal ${ }^{1,2^{*}}$

\begin{abstract}
Background: The viral hemorrhagic septicemia virus (VHSV) is one of the most serious fish pathogens. In 2003, a novel sublineage (genotype IVb) of this deadly virus emerged in the Great Lakes basin causing serious fish kills. We have previously demonstrated that a DNA plasmid (pcDNA), containing a cytomegalovirus (CMV) promoter and the viral hemorrhagic septicemia virus (VHSV) genotype IVb glycoprotein (G) gene insert (designated pVHSivb-G) confers moderate protection in muskellunge (Esox masquinongy), a highly susceptible species upon challenge. In order to achieve optimal protection, we investigated a number of factors including the incubation time [i.e. the number of degree days $\left({ }^{\circ}\right.$ days)] before challenge, and viral challenge dose and route. Additionally, we tested if pVHSivb-G provides protection against VHSV-IVb to less susceptible salmonids such as rainbow trout (Oncorhynchus mykiss), brown trout (Salmo trutta) and lake trout (Salvelinus namaycush).

Results: An increase in the period lapsed between vaccination and challenge to $1880^{\circ}$ days resulted in $95 \%$ relative percent protection (RPS) in muskellunge following a single administration of the pVHSivb-G plasmid and viral challenge. An RPS of $100 \%$ for muskellunge was achieved with a longer incubation period $\left(2400^{\circ}\right.$ days) and in conjunction with a booster dose of the plasmid. The pVHSivb-G vaccine also elicited significant protection in all three salmonid species, reaching 100\% RPS in lake trout following an incubation period of $1001^{\circ}$ days prior to viral challenge. Vaccination with pVHSivb-G was also associated with the development of significant levels of circulating VHSV-binding antibodies in muskellunge as measured by indirect ELISA, which reached peak levels 6-7 weeks post-vaccination. Viral shedding in vaccinated survivors was minimal and of transient nature.
\end{abstract}

Conclusions: The study shows that the pVHSivb-G plasmid can elicit a protective response against the wild virus strain in a range of species important in recreational and commercial Great Lakes fisheries.

Keywords: DNA vaccine, Viral hemorrhagic septicemia virus, Fish

\footnotetext{
* Correspondence: faisal@cvm.msu.edu

${ }^{1}$ Department of Pathobiology and Diagnostic Investigation, College of

Veterinary Medicine, Michigan State University, East Lansing, Ml 48824, USA

${ }^{2}$ Department of Fisheries and Wildlife, College of Agriculture and Natural

Resources, Michigan State University, East Lansing, MI 48824, USA
} 


\section{Background}

The emergence of a novel Novirhadovirus, viral hemorrhagic septicemia virus (VHSV) genotype (IVb) in the Laurentian Great Lakes basin of North America alarmed fishery managers and researchers to the consequences its spread could bring to cultured and wild fish populations $[1,2]$. This VHSV sublineage has an unusually wide host range, infecting 28 fish species, with muskellunge (Esox masquinongy) being the most susceptible species documented to date [3-6]. In the Great Lakes basin, numerous state and federal fish hatcheries are involved in propagation and stocking of a variety of fish species whose populations have been drastically suppressed from historical levels and in some cases are at risk of being endangered [7]. Of these fish stocks, millions of muskellunge and salmonid fry and fingerlings are annually propagated and released throughout the basin to support recreational and commercial fisheries. Salmon, lake sturgeon (Acipenser fulvescens), and muskellunge propagation relies on the collection of gametes from wild fish, while other programs [(e.g., rainbow trout (Oncorhynchus mykiss), brown trout (Salmo trutta), and lake trout (Salvelinus namaycush)] raise captive broodstocks [8]. Field observations and experimental studies have clearly demonstrated differing species susceptibility to VHSV-IVb, with salmonids exhibiting low to moderate susceptibility $[2,4,5]$. While the risks of VHSV-IVb are highest to the basin-wide muskellunge rehabilitation program, there are major concerns that salmonids may also aid in virus dissemination. This is particularly true since VHSV-IVb has been previously detected in apparently healthy salmonid species and gametes (reviewed in Faisal et al. [2]). To date, stringent biosecurity measures along with regulation of live fish transfer have successfully prevented VHSV-IVb from infecting hatchery populations. However, culture practices relying upon gamete collection from wild-fish and the stocking of progeny in public waters engender risks of VHSV-IVb introduction into hatcheries and consequently the potential of propagated fish to transmit VHSV-IVb upon stocking [9]. As a result, there is an urgent need to develop an efficacious VHSV vaccine that can protect multiple propagated fish species.

In a previous study, we explored the usefulness of a DNA-vaccine preparation, incorporating the VHSV-IVb glycoprotein (G) gene under the control of a human cytomegalovirus (CMV) promoter in protecting muskellunge upon challenge with the wild virus [10]. In that study, $539^{\circ}$ days following an intramuscular administration (IM) of the plasmid, fish were immersion challenged with $10^{5}$ VHSV-IVb plaque forming units (pfu) $\mathrm{mL}^{-1}$. While administration of the $G$ gene plasmid elicited the development of neutralizing antibodies, protection following challenge was moderate, achieving $45 \%$ relative percent survival (RPS) [10]. Encouraged by these results, the first aim of the present study was to optimize protective efficacy in vaccinated muskellunge by modifying a number of factors in the vaccination regimen such as time between vaccination and challenge, virus challenge dose, and the number of vaccine doses administered. We further investigated if vaccinated fish that survive infection were able to mount a humoral immune response and whether survivors continued to harbor and shed the VHSV-IVb. The second aim of the study was to determine if this same vaccine preparation could also be used to protect three representative genera of salmonids found in the Great Lakes basin: rainbow trout, brown trout and lake trout.

\section{Methods}

Fish

Two groups of muskellunge were used in this study. The first group of muskellunge, used in the first two muskellunge trials (MUS-1 and MUS-2), was obtained 16 weeks post-hatch [average $14.2 \mathrm{~cm} \quad(S D=1.4)$ fork length, $11.9 \mathrm{~g}(S D=3.8)$ ] from Chautauqua State Fish Hatchery (New York Department of Environmental Conservation, Chautauqua, NY). The second group of muskellunge, used in the third trial (MUS-3), was obtained 14 weeks post-hatch [average $15.6 \mathrm{~cm} \quad(S D=0.8)$ fork length, $16.0 \mathrm{~g}(S D=1.1)]$ from Wolf Lake State Fish Hatchery [Michigan Department of Natural Resources (MDNR), Mattawan, MI)]. Rainbow trout (land-locked Eagle Lake morphotype) were obtained 12 weeks post-hatch [average of $3.6 \mathrm{~cm}(S D=0.4)$ fork length, $0.7 \mathrm{~g}(S D=0.3)$ ] from the Oden State Fish Hatchery (MDNR, Alanson, MI). Brown trout (Gilchrest morphotype) were obtained 16 weeks post-hatch [average $7.5 \mathrm{~cm}(S D=1.1)$ fork length, $4.2 \mathrm{~g}(S D=1.7)$ ] also from the Oden State Fish Hatchery. Lake trout (Lake Superior strain) were obtained 18 weeks post-hatch [average $17.6 \mathrm{~cm}(S D=1.4)$ fork length, $24.1 \mathrm{~g}(S D=6.5)]$ from Marquette State Fish Hatchery (MDNR, Marquette, MI).

All fish were certified to be free of important diseases according to World Organization for Animal Health (OIE) testing guidelines [11]. Fish were acclimated in 500$\mathrm{L}$ circular fiberglass tanks in a continuous flow-through system with facility-chilled well water $\left(11^{\circ} \mathrm{C}\right)$ and supplemental aeration. Vaccination and experimental challenges were performed at the Michigan State University Research Containment Facility (East Lansing, MI). Muskellunge were fed live fathead minnows (Pimephales promelas) obtained from Anderson Farms Inc. (Lonoke, AR) that were certified free of important diseases according to OIE guidelines. An additional 60 fathead minnows were necropsied and underwent additional testing according to the American Fisheries Society guidelines [12]. Rainbow trout and lake trout were fed Skretting dry pellets (Skretting USA; Tooele, UT), while brown 
trout were fed Nelson's Silver Cup trout feed (Harrietta Hills, Harrietta, MI). All fish were fed ad libitum throughout the study except for muskellunge during the 1st week post viral challenge when minnows were withheld. Two weeks prior to immunization, fish were randomly distributed among 72-L polyethylene flow-through tanks (Pentair Aquatic Eco-Systems, Apopka, FL) with supplemental aeration.

\section{Virus and cell culture}

The VHSV genotype IVb isolate used in this study was the Great Lakes index strain MI03 [1]. The isolate has been maintained by continuous subculture in the cell line epithelioma papulosum cyprini (EPC). The EPC cell line was maintained and subcultured in $150-\mathrm{cm}^{2}$ tissue culture flasks (Corning Inc., Corning, NY) at $25^{\circ} \mathrm{C}$ using a basal media of Earle's salt-based minimal essential medium (MEM) (Invitrogen Corp., Carlsbad, CA) and supplemented with $29.2 \mathrm{mg} \mathrm{ml}^{-1}$ L-glutamine (Invitrogen), penicillin (100 IU mL $^{-1}$ ) (Invitrogen), streptomycin (0.1 $\mathrm{mg} \mathrm{mL}^{-1}$ ) (Invitrogen), 10\% fetal bovine serum (Gemini Bio Products, West Sacramento, CA), and sodium bicarbonate $(7.5 \%$ w/v) (Sigma, St. Louis, MO). Viable viral concentrations were determined using plaque assay on EPC cell line using polyethylene glycol and a methylcellulose overlay [13, 14]. Virus was then aliquoted into cryogenic vials (Corning) for one time use and stored at $-80^{\circ} \mathrm{C}$.

\section{Construction of pVHSivb-G plasmid}

The pcDNA_3.1 (+) is a commercially available vector containing the human CMV immediate-early promoter. The DNA vaccine construct containing the VHSV-IVb glycoprotein gene (designated pVHSivb-G, [10]) was modeled after successful DNA vaccines against VHSV genotype I [15, 16] and IHNV [17]. The construction and production of this plasmid were outsourced to Life Technologies (Carlsbad, CA). In brief, an EcoRI restriction site (G/AATTC) followed by a kozak consensus sequence terminating with the first amino acid of the complete MI03GL VHSV-IVb isolate glycoprotein gene (1524 bp) was synthesized; an XbaI restriction site (T/CTAGA) was then added following the 3 ' termination codon. The assembled fragment was then digested using the described endonucleases and subcloned into the eukaryotic expression vector pcDNA $3.1(+)$ (Invitrogen). The plasmid was transformed and propagated into K12 Escherichia coli. Sequencing confirmed the correct glycoprotein gene sequence and orientation. The pcDNA $3.1(+)$ vector without the glycoprotein gene was similarly propagated and used as a negative (mock) control. Both plasmids were suspended in sterile PBS and stored at $-80{ }^{\circ} \mathrm{C}$ until use.
The final products were designated pVHSivb-G and pcDNA (mock).

\section{Vaccination and challenge}

Immediately prior to vaccination, all plasmid vectors were thawed and diluted to $10 \mu \mathrm{g}$ in $100 \mu \mathrm{L}$ sterile PBS. Randomly selected fish were anesthetized with $0.1 \mathrm{~g} \mathrm{~L}^{-1}$ of tricaine methanesulfonate (MS-222) (Western Chemical Inc., Ferndale, WA) and buffered with $0.3 \mathrm{~g} \mathrm{~L}^{-1}$ sodium bicarbonate. All fish were immunized IM with $10 \mu \mathrm{g}$ of plasmid DNA in the left epaxial musculature. Nine trials took place which varied in number of ${ }^{\circ}$ days (540 to 2400) within which fish were allowed to mount immune response prior to challenge. For all the trials using the three salmonid species, fish were allowed to mount an immune response for $1001^{\circ}$ days prior to challenge. Additionally, booster doses were applied following $940^{\circ}$ days in MUS-2 and MUS-3, and to a subset of individuals following $546^{\circ}$ days in the salmonids trials. Fish were VHSV challenged using either intraperitoneal injection or immersion challenge. In trials using immersion challenge (see below), viral challenges were conducted in glass aquaria containing $32 \mathrm{~L}$ of chilled well water and supplemental external aeration. Fish were challenged via immersion in static water containing infectious virus for $60 \mathrm{~min}$. All negative challenge controls were similarly challenged with minimal essential media. After $60 \mathrm{~min}$, fish were returned to their respective tanks and monitored daily for morbidity and mortality for 28 days. Kidney, spleen and heart samples were collected from all mortalities, and inoculated onto EPC monolayers. After 14 days, supernatant was removed, frozen at $-80{ }^{\circ} \mathrm{C}$, thawed at centrifuged at $2700 \mathrm{~g}$ for $15 \mathrm{~min}$ at $4{ }^{\circ} \mathrm{C}$. Supernatant was then re-infected onto fresh EPC monolayer and incubated for 14 days before being examined for viral cytopathic effect (CPE). RNA from suspicious samples was then extracted using the QIAamp Viral RNA kit and following the manufacturer's instructions. The presence of VHSV was confirmed using real-time reverse transcription polymerase chain reaction (RT-qPCR) assay specific for VHSV $[18,19]$.

\section{Muskellunge trials}

In the first muskellunge trial (MUS-1), muskellunge were given a single $10 \mu \mathrm{g}$ administration of either pVHSivb-G or pcDNA plasmids $\left(n=20\right.$ plasmid $\left.^{-1}\right)$ and allowed to mount an immune response for $1880^{\circ}$ days (24 weeks at $11{ }^{\circ} \mathrm{C}$ ). Fish were divided into 2 tanks containing 10 fish each per preparation. An additional tank containing 10 muskellunge for each treatment was maintained throughout the study as non-infected controls. Experimental tanks

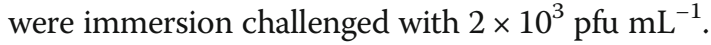

The second muskellunge trial (MUS-2) was identical to MUS-1 except after $940^{\circ}$ days (12 weeks in $11{ }^{\circ} \mathrm{C}$ water), a booster dose of $10 \mu \mathrm{g}$ of their respective 
plasmid was administered to each fish. Following a second period of $940^{\circ}$ days, fish were immersion challenged with $2 \times 10^{3}$ pfu $\mathrm{mL}^{-1}$ VHSV-IVb.

This third muskellunge trial (MUS-3) was nearly identical to that of MUS-2 except that fish were challenged $1460^{\circ}$ days (an additional $520^{\circ}$ days) following booster administration. Muskellunge therefore had a total of $2400^{\circ}$ days to mount an immune response. Experimental tanks were challenged with $2 \times 10^{3} \mathrm{pfu} \mathrm{mL}^{-1}$.

\section{Rainbow trout trials}

The two rainbow trout trials (RBT-1, RBT-2) differed in conditions only in the VHSV challenge route. In both trials, fish were immunized IM with the pVHSivb-G or pcDNA plasmids (RBT-1: $n=39$ [pVHSivb-G] and 29 [pcDNA]; RBT-2: $n=48$ [pVHSivb-G] and 35 [pcDNA]). Fish from each treatment were returned to separate 72 $\mathrm{L}$ tanks and maintained throughout the study. After $546^{\circ}$ days (6 weeks in $13{ }^{\circ} \mathrm{C}$ water), a portion of the pVHSivb$\mathrm{G}$ vaccinated fish were administered a $10 \mu \mathrm{g}$ booster dose ( $n=13$ [RBT-1] and 31 [RBT-2] respectively). Rainbow trout were then allowed to build an immune response for an additional $455^{\circ}$ days prior to challenge $\left(1001^{\circ}\right.$ days or 11 weeks at $13{ }^{\circ} \mathrm{C}$ post initial vaccination). Fish from RBT-1 were anesthetized and challenged by intraperitoneal (IP) injection with $9.5 \times 10^{5}$ pfu in $100 \mu \mathrm{L}$ of sterile PBS. The negative control tank received sterile PBS. Fish from RBT-2 were challenged by immersion with $9.5 \times 10^{4}$ pfu $\mathrm{mL}^{-1}$.

\section{Brown trout trials}

Trials with brown trout (BNT-1, BNT-2) were the same as rainbow trout trials in respect to conditions and viral challenge. Brown trout were immunized IM with $10 \mu \mathrm{g}$ of pVHSivb-G or pcDNA plasmids (BNT-1: $n=56$ [pVHSivb-G] and 26 [pcDNA]; BNT-2: $n=50$ [pVHSivbG] and 28 [pcDNA]).. After $546^{\circ}$ days $\left(6\right.$ weeks in $13{ }^{\circ} \mathrm{C}$ water), $(n=18$ [BNT-1] and 25 [BNT-2]), pVHSivb immunized brown trout received a $10 \mu \mathrm{g}$ booster vaccine dose and were challenged $455^{\circ}$ days later.

\section{Lake trout trials}

For comparison purposes, the vaccination regimen in the two lake trout trials (LAT-1, LAT-2) was identical to the rainbow and brown trout trials. However, in lake trout trials the immersion challenge route was not performed, instead we used two IP challenge concentrations. Lake trout were immunized IM with the PVHSivb-G or pcDNA plasmids (both trials: $n=61$ [pVHSivb-G] and 26 [pcDNA]). After $546^{\circ}$ days $\left(6\right.$ weeks in $13{ }^{\circ} \mathrm{C}$ water), ( $n=27$ for both LAT-1 and LAT-2), pVHSivb immunized lake trout received a $10 \mu \mathrm{g}$ booster dose. Fish were challenged $455^{\circ}$ days later. Fish in LAT-1 were IP challenged with $9.5 \times 10^{5}$ pfu in $100 \mu \mathrm{L}$ PBS while lake trout in LAT-2 were IP challenged with $4.75 \times 10^{6} \mathrm{pfu}$ in $500 \mu \mathrm{L}$ of PBS (i.e., a five-fold greater VHSV concentration compared to LAT-1),

\section{Detection of anti-VHSV antibodies in muskellunge sera using an indirect ELISA procedure}

To examine the humoral response associated with the pVHSivb-G plasmid, blood samples were collected from 27 muskellunge from the Chautauqua State Fish Hatchery 2 weeks prior to immunization. Following collection, blood was stored at $4{ }^{\circ} \mathrm{C}$ for $2 \mathrm{~h}$ and centrifuged at $2700 \mathrm{~g}$ for $10 \mathrm{~min}$ at $4{ }^{\circ} \mathrm{C}$. Serum was then aliquoted and stored at $-80{ }^{\circ} \mathrm{C}$ until analysis. Muskellunge then received an intramuscular vaccination of $10 \mu \mathrm{g}$ of the pVHSivb-G preparation. Sera was collected and processed as described above every 2 weeks until 10 weeks $\left(770^{\circ}\right.$ days) post vaccination. Half of the fish $(n=15)$ were then immersion challenged with $2 \times 10^{3}$ pfu $\mathrm{mL}^{-1}$ as previously described. Sera were then collected from muskellunge $6,12,15,18$, 20,30 and 34 weeks post challenge. All sera samples were analyzed using a newly developed and optimized muskellunge specific indirect ELISA to assess circulating antiVHSV antibodies [20].

Prior to ELISA, serum was heat inactivated at $45{ }^{\circ} \mathrm{C}$ for $30 \mathrm{~min}$. Serum was centrifuged at $2700 \mathrm{~g}$ for $10 \mathrm{~min}$. at $4{ }^{\circ} \mathrm{C}$ immediately prior to dilution in a solution of $1 \%$ nonfat dried milk in PBS (dilution of PBS-5\% NFDM, Sigma). Indirect ELISA took place in polystyrene microplates (96-well, Microlon ${ }^{\circ} 600$ with chimney wells; Greiner Bio-One, Monroe, NC). Plates were sealed during all incubation periods (SealPlate; Sigma) and washed 5 times following each incubation period unless otherwise stated using PBS containing 0.05\% Tween 20 (PBS-T20; Sigma) in an automated microplate washer (BioTek, $4 \mathrm{~L} \times 405^{\mathrm{mi}}$ plate washer; Winooski, VT).

Briefly, microtiter assay plates were coated with $100 \mu \mathrm{L}$ well $^{-1}$ of purified VHSV-IVb at $1 \mu \mathrm{g} \mathrm{mL}^{-1}$ and incubated overnight $(14-16 \mathrm{~h})$ at $4{ }^{\circ} \mathrm{C}$ in a humid chamber. After incubation, plates were washed and unbound sites were blocked with the addition of $430 \mu \mathrm{L}$ well ${ }^{-1}$ of PBS containing 5\% NFDM (PBS-5\%; Sigma) and incubation at $37{ }^{\circ} \mathrm{C}$ for $1 \mathrm{~h}$. Heat inactivated and diluted test and control muskellunge sera was then added to duplicate wells at $100 \mu \mathrm{L}$ well ${ }^{-1}$. After incubating at $25{ }^{\circ} \mathrm{C}$ for $1 \mathrm{~h}$, plates were washed and $100 \mu \mathrm{L}$ of $1: 30,000$ dilution of the 3B10 mouse anti-muskellunge-IgM mAb was added to all wells and again incubated at $25^{\circ} \mathrm{C}$ for $1 \mathrm{~h}$. Plates were washed and $100 \mu \mathrm{L}$ of 1:4,000 dilution of a commercially available goat anti-mouse secondary horseradish peroxidase (HRP) conjugated antibody (Invitrogen) was added to each well and incubated at $25^{\circ} \mathrm{C}$ for $1 \mathrm{~h}$. Plates were developed by the addition of $100 \mathrm{uL}$ of $0.4 \mathrm{mg} \mathrm{mL} \mathrm{m}^{-1} o$-phenylenediamine (Sigma) in phosphate citrate buffer (Sigma) containing $3 \mathrm{mM}$ hydrogen 
peroxide (Avantor Performance Materials Inc., Center Valley, PA). The reaction proceeded for $30 \mathrm{~min}$ at $25{ }^{\circ} \mathrm{C}$ in the dark and was stopped with the addition of $50 \mathrm{~L}$ of $3 \mathrm{M}$ sulfuric acid $\left(\mathrm{H}_{2} \mathrm{SO}_{4}\right.$; Avantor Performance Materials). The optical density (OD) was read at $490 \mathrm{~nm}$ using a BioTek, ELx808 ${ }^{\text {Tw }}$ plate reader (BioTek) and the Gen5 software (BioTek). The average value of blank wells was subtracted from test and control wells prior to analysis. A threshold of 0.163 was used as the basis for distinguishing between presence/absence of circulating antibodies [20].

\section{Assessment of VHSV shedding by vaccinated and challenged muskellunge}

Surviving vaccinated muskellunge from the MUS-2 and MUS-3 trials were used to examine for the presence of VHSV shedding. Samples were collected beginning 4 weeks post challenge and every 4 weeks for 28 weeks. Shedding analysis was conducted using a slightly modified protocol of that described by Kim and Faisal [21]. Briefly, individual surviving fish were transferred to glass aquaria containing $4 \mathrm{~L}$ of static facility chilled well water containing supplemental aeration. After $120 \mathrm{~min}$, water was mixed and a $50 \mathrm{~mL}$ water sample was taken and fish were placed back into their original tanks. Samples were stored at $4{ }^{\circ} \mathrm{C}$ until processing within $24 \mathrm{~h}$. For processing, samples were vortexed and centrifuged at $2700 \mathrm{~g}$, at $4{ }^{\circ} \mathrm{C}$ for $10 \mathrm{~min}$. After centrifugation, a viral plaque assay (VPA) was conducted as previously described. After 6 days, cell monolayers were stained with crystal violet (Sigma) and 18\% formaldehyde (Avantor Performance Materials Inc.).

\section{Statistical analysis}

For muskellunge trials (MUS-1,2,3) Kaplan-Meier survival estimates and mean time to death accounting for right censoring of survival data (i.e., mortality did not occur during the 28 day monitoring period) were calculated for each tank of fish using PROC LIFETEST in SAS [22]. Cox proportional hazards frailty models with tank as a random effect to account for fish deaths within tanks not being independent were also calculated for all trials using PROC PHREG in SAS. In all trials, the cumulative mortality was averaged across replicate tanks when possible for each trial to calculate RPS for each treatment [23].

$$
\mathrm{RPS}=1-\left(\frac{\% \text { cumulative mortality of vaccinated }}{\% \text { cumulative mortality of mock vaccinated }}\right) \times 100
$$

In muskellunge trials (MUS-1,2,3), significant differences in cumulative mortality between or among treatments within a trial were tested using t-tests conducted using PROC TTEST in SAS. While, due to a lack of replication in the salmonid trials, statistical significance was analyzed using a conventional two-tailed $x^{2}$-test.

The humoral response in pVHSivb-G vaccinated and challenged muskellunge were initial examined using a paired $t$-test and subsequently analyzed using quantile regression, which allowed us to more fully examine the conditional relationship of the humoral response over time. Separate regression models were estimated for post vaccination and post challenge responses. Conditional $0.50,0.75$, and 0.90 quantile regressions were fit to each set of data. Quantile regression allows a more thorough examination of the conditional relationship between dependent and independent variables; for example, it can determine if the rate of change in more extreme values of the dependent variable is different than the change for central tendency values [24]. For model fitting, OD values were $\log _{e}$ transformed with time (i.e., post vaccination or post challenge times) up to its third power used as explanatory variables. The significance of explanatory variables (i.e., time, square of time, cube of time) was tested using likelihood ratio tests. If an explanatory variable was not statistically significant, it was excluded as an explanatory variable and the model was refit. 95\% confidence intervals for parameter estimates from the quantile regression models were obtained by resampling with the number of resampling iterations set at 1,000. Quantile regression models were fit in SAS using PROC QUANTREG.

\section{Ethics statement}

All experiments were conducted in accordance with the ethical guidelines defined by Michigan State University's (MSU) Institutional Animal Care and Use Committee (AUF 03/14-047-00).

\section{Results}

\section{Vaccine efficacy in muskellunge}

For the MUS-1 trial, the two replicate tanks of muskellunge that received the $\mathrm{pVHSivb-G}$ plasmid experienced 0 and $10 \%$ cumulative mortality whereas the pcDNA plasmid replicates both experienced 100\% mortality (Table 1), resulting in a mean RPS of $95 \%$. The mean day of death for the pcDNA plasmid treatments was $11.0(\mathrm{SE}=1.0)$ and 12.4 $(\mathrm{SE}=1.3)$ whereas the mean day of death for the pVHSivb-G plasmid treatment was 16.0 $(\mathrm{SE}=\mathrm{NA})$ (mean day to death was only calculable for one tank and standard errors could not be calculated) (Table 1). The hazard ratio comparing the pVHSivb-G and pcDNA plasmids estimated from the Cox proportional hazards frailty model was 0.016 (95\% confidence limits: 0.002-0.124), suggesting the pVHSivb-G treatment significantly reduced the hazard rate for muskellunge (Table 1). There was a statistically significant difference in cumulative mortality between the pVHSivb-G and mock 
Table 1 Summary of the three trials conducted using muskellunge (MUS-1, 2, 3)

\begin{tabular}{|c|c|c|c|c|c|c|c|}
\hline & Fish & Cumulative mortality & Mean Cumulative Mortality & Mean day to death \pm SE & HR $(95 \% \mathrm{Cl})$ & RPS & $P$-value \\
\hline \multicolumn{8}{|l|}{ MUS-1 } \\
\hline pVHSivb-G & 10 & $0 \%$ & $5 \%$ & NA & $0.016(0.002-0.124)$ & $95 \%$ & 0.003 \\
\hline pVHSivb-G & 10 & $10 \%$ & & & & & \\
\hline pcDNA & 10 & $100 \%$ & $100 \%$ & $11.7 \pm 1.3$ & & NA & NA \\
\hline pcDNA & 10 & $100 \%$ & & & & & \\
\hline \multicolumn{8}{|l|}{ MUS-2 } \\
\hline pVHSivb-G & 10 & $30 \%$ & $15 \%$ & $10.6 \pm 0.4$ & $0.063(0.018-0.223)$ & $85 \%$ & 0.030 \\
\hline pVHSivb-G & 10 & $0 \%$ & & & & & \\
\hline pcDNA & 10 & $100 \%$ & $100 \%$ & $9.9 \pm 1.0$ & & NA & NA \\
\hline pcDNA & 10 & $100 \%$ & & & & & \\
\hline \multicolumn{8}{|l|}{ MUS-3 } \\
\hline pVHSivb-G & 10 & $0 \%$ & $0 \%$ & NA & NA & $100 \%$ & $<0.0001$ \\
\hline pVHSivb-G & 10 & $0 \%$ & & & & & \\
\hline pcDNA & 10 & $100 \%$ & $100 \%$ & $12.8 \pm 1.8$ & & NA & NA \\
\hline
\end{tabular}

treatments ( $t$-test: $t=-19.00, \mathrm{df}=2, P$-value $=0.003)$. During necropsy, muskellunge exhibited characteristic clinical signs of acute VHSV infection including extensive petechial to ecchymotic hemorrhage throughout the musculature, liver, swim bladder and renal mesentery. Numerous fish exhibited severely pale gills, liver, and heart. VHSV$\mathrm{IVb}$ was re-isolated from all of the mortalities on the EPC cell line.

In the second muskellunge trial (MUS-2), replicate tanks of pVHSivb-G vaccinated muskellunge challenged $2400^{\circ}$ days post-vaccination (PV, $940^{\circ}$ days post booster administration) experienced 0 and $30 \%$ mortality (Table 1 ), with mean day of death of $10.6(\mathrm{SE}=0.4)$ days (mean day of death could not be calculated for the other replicate since no mortalities occurred). Conversely, the pcDNA plasmid replicates experienced $100 \%$ mortality with mean day of death of $9.3(\mathrm{SE}=0.9)$ and 10.4 $(\mathrm{SE}=0.9)$ days, resulting in an RPS of $85 \%$. The hazard ratio comparing the pVHSivb-G and pcDNA mock treatments was 0.063 (95\% confidence limits: 0.018-0.223) (Table 1) suggesting the pVHSivb-G treatment significantly reduced the hazard rate for muskellunge. Cumulative mortality between the pVHSivb-G and pcDNA treatments was significantly different ( $t$-test: $t=5.67, \mathrm{df}=2, P$-value $=0.030)$. During necropsy, mortalities again exhibited distinct signs of acute VHSV-IVb infection.

In MUS-3, pVHSivb-G vaccinated muskellunge challenged $2400^{\circ}$ days post-vaccination ( $\mathrm{PV}, 940^{\circ}$ days post booster administration) experienced $0 \%$ mortality while the pcDNA mock replicates experienced 100\% mortality resulting in $100 \%$ RPS (Table 1 ). The mean day of death of the pcDNA replicates were $12.2(\mathrm{SE}=1.7)$ and 13.4 $(\mathrm{SE}=1.7)$ days. This was clearly a significant level of protection. However, the hazard ratio between the treatments could not be calculated because of the lack of variability in treatment results. Similarly, the lack of variability in the treatment results resulted in questionable $t$-test results with regards to differences in cumulative mortality ( $t$-test: $t=\infty, \mathrm{df}=2, P$-value $<0.0001)$ (Table 1$)$.

\section{Vaccine efficacy in salmonids}

Mock-vaccinated rainbow trout in RBT-1 experienced $62 \%$ cumulative mortality following IP challenge (Table 2). In contrast, rainbow trout vaccinated with pVHSivb-G experienced only 30\% cumulative mortality following a single administration and 15\% mortality with two administrations. Significant protection was observed in $\mathrm{G}$ gene treatments, with $57 \%$ RPS $\left(\chi^{2}=6.83, \mathrm{df}=1\right.$, $P$-value $=0.009)$ and $75 \% \operatorname{RPS}\left(\chi^{2}=7.84, \mathrm{df}=1, P\right.$-value $=0.005)$ following one or two pVHSivb-G administration respectively (Table 2 ). In $\mathrm{RBT}-2$, only $9 \%$ mortality of the mock-vaccinated fish was observed following challenge by immersion with the virus and none of the pVHSivb immunized trout died (Table 2). Due to low mortality experience in rainbow trout using immersion infection, significant protection was not observed. All mortalities exhibited clinical signs of VHSV infection including mild to moderate petechial to ecchymotic hemorrhage throughout the musculature, liver, swim bladder and renal mesentery. VHSV was re-isolated from all of the mortalities. 
Table 2 Results of vaccination trials in three salmonid species

\begin{tabular}{|c|c|c|c|c|c|}
\hline Treatment & Fish & $\begin{array}{l}\text { Cumulative } \\
\text { Mortality }\end{array}$ & RPS & $x^{2}$ & $P$-value \\
\hline \multicolumn{6}{|l|}{$\overline{\text { RBT-1 }}$} \\
\hline pcDNA & 29 & $62.1 \%$ & & & \\
\hline pVHSivb-G & 26 & $26.9 \%$ & $56.7 \%$ & 6.83 & 0.009 \\
\hline pVHSivb-G (2 doses) & 13 & $15.4 \%$ & $75.2 \%$ & 7.84 & 0.005 \\
\hline \multicolumn{6}{|l|}{ RBT-2 } \\
\hline pcDNA & 35 & $8.6 \%$ & & & \\
\hline pVHSivb-G & 17 & $0.0 \%$ & $100.0 \%$ & 1.55 & 0.214 \\
\hline pVHSivb-G (2 doses) & 31 & $0.0 \%$ & $100.0 \%$ & 2.78 & 0.095 \\
\hline \multicolumn{6}{|l|}{ BNT-1 } \\
\hline pcDNA & 26 & $23.1 \%$ & & & \\
\hline pVHSivb-G & 38 & $5.3 \%$ & $77.2 \%$ & 4.48 & 0.034 \\
\hline pVHSivb-G (2 doses) & 18 & $16.7 \%$ & $27.8 \%$ & 0.27 & 0.604 \\
\hline \multicolumn{6}{|l|}{ BNT-2 } \\
\hline pcDNA & 28 & $10.7 \%$ & & & \\
\hline pVHSivb-G & 25 & $4.0 \%$ & $62.7 \%$ & 0.85 & 0.356 \\
\hline pVHSivb-G (2 doses) & 25 & $4.0 \%$ & $62.7 \%$ & 0.85 & 0.356 \\
\hline \multicolumn{6}{|l|}{ LAT-1 } \\
\hline pcDNA & 26 & $30.7 \%$ & & & \\
\hline pVHSivb-G & 34 & $0.0 \%$ & $100.0 \%$ & 12.07 & 0.0005 \\
\hline pVHSivb-G (2 doses) & 27 & $0.0 \%$ & $100.0 \%$ & 9.79 & 0.0018 \\
\hline \multicolumn{6}{|l|}{ LAT-2 } \\
\hline pcDNA & 26 & $34.6 \%$ & & & \\
\hline pVHSivb-G & 34 & $0.0 \%$ & $100.0 \%$ & 13.85 & 0.0002 \\
\hline pVHSivb-G (2 doses) & 27 & $0.0 \%$ & $100.0 \%$ & 11.26 & 0.0008 \\
\hline
\end{tabular}

Rainbow trout (RBT-1 and RBT-2), brown trout (BNT-1 and BNT-2) and lake trout (LAT-1 and LAT-2) vaccine trials. Table includes the number of fish in each treatment, the cumulative mortality and the relative percent survival (RPS) and the associated $P$-value calculated using a two-tailed $x^{2}$-test

In the first brown trout trial (BNT-1), mock-vaccinated brown trout experienced 23\% cumulative mortality (Table 2) following IP challenge. Fish vaccinated with pVHSivb-G experienced 5\% cumulative mortality with a single administration and $17 \%$ cumulative mortality following two administrations resulting in $77 \%$ and $28 \%$ RPS respectively. Protection was only significant in the treatment that received a single administration of the pVHSivb-G plasmid $\left(x^{2}=4.48, \mathrm{df}=1, P\right.$-value $\left.=0.034\right)$. In BNT-2, mock-vaccinated brown trout individuals experienced $11 \%$ cumulative mortality following immersion challenge (Table 2). The cumulative mortality of both the vaccinated treatments was $4 \%$ (63\% RPS), resulting from only a single individual dying in both the treatments. Mortalities were again too low to determine significant protection. The virus was isolated from all mortalities, though brown trout exhibited milder clinical signs of VHSV infection including less petechial hemorrhage throughout the liver, swim bladder and renal mesentery.
In LAT-1, the mock-vaccinated lake trout experienced $31 \%$ cumulative mortality (Table 2). Meanwhile, not a single vaccinated individual from $\mathrm{G}$ gene treatments succumbed. Lake trout experienced significant protection with $100 \%$ RPS in both $G$ gene treatments $\left(\chi^{2}=12.07\right.$, $\mathrm{df}=1, P$-value $=0.0005$ with a single administration), $\left(X^{2}=9.79, \mathrm{df}=1, P\right.$-value $=0.0018$ with two administrations). While, in the second lake trout trial (LAT-2), when IP challenged with a five-fold higher viral concentration, the mock-vaccinated treatment experienced 35\% cumulative mortality while none of the vaccinated fish died (Table 2), resulting in 100\% RPS and significant protection $\left(x^{2}=13.85, \mathrm{df}=1, P\right.$-value $=0.0002$ with a single administration, and $X^{2}=11.26, \mathrm{df}=1, P$-value $=$ 0.0008 with two administrations). Lake trout mortalities exhibited clinical signs of VHSV infection as previously described and VHSV was isolated from all mortalities.

\section{Development of circulating anti-VHSV antibody response in pVHSivb-G vaccinated muskellunge}

Prior to vaccination the $\mathrm{OD}$ levels in the 27 naïve muskellunge were $0.008(S D=0.008)$. Anti-VHSV antibodies did not appear to significantly increased until measured 28 days following vaccination, at which point the mean OD value had reached $0.248(S D=$ 0.184 ) (paired $t$-test: $t=6.18, \mathrm{df}=23, P$-value $<0.0001$ ). Anti-VHSV antibody levels appeared to peak between 42 days $[0.315(S D=0.313)]$ and 56 days $[(0.3 .72(S D=$ $0.256)$ ] post exposure. Though, to precisely predict peak antibody levels and the duration of the secondary antiVHSV antibody response following challenge, quantile regression analysis was utilized.

For all evaluated quantiles, the cube of time postvaccination $(\mathrm{PV})$ was not statistically significant by likelihood ratio testing and was dropped from the models (0.50: $\mathrm{x}^{2}=3.30, \mathrm{df}=1, P$-value $=0.069 ; 0.75: \mathrm{x}^{2}=1.47, \mathrm{df}$ $=1, P$-value $=0.226 ; \quad 0.90: \quad \mathrm{x}^{2}=3.80, \quad \mathrm{df}=1, \quad P$-value $=$ $0.051)$. However, the square of time PV was statistically significant $(P$-value $<0.0001)$ for all models. The functional form of the quantile regression fitted relationships for the OD values was similar across the quantiles, and could perhaps best be characterized as bell-shaped (Fig. 1). The model corresponding to a 0.90 quantile had a somewhat steeper relationship then the other models as a consequence of a few outlying OD values at between 4 and 10 weeks post-challenge (Table 3). Based on predicted relationships from the fitted quantile regression models, OD values would increase to a value 0.163 by 3 to 4.25 weeks depending on the quantile (Fig. 1). Peak OD values would occur at around 7 weeks post vaccination, and would then decline back to 0.163 at around 10 to 11 weeks post vaccinations (Fig. 1).

For the quantile regression models fit to the post challenge data, the cube of time post-challenge was not 


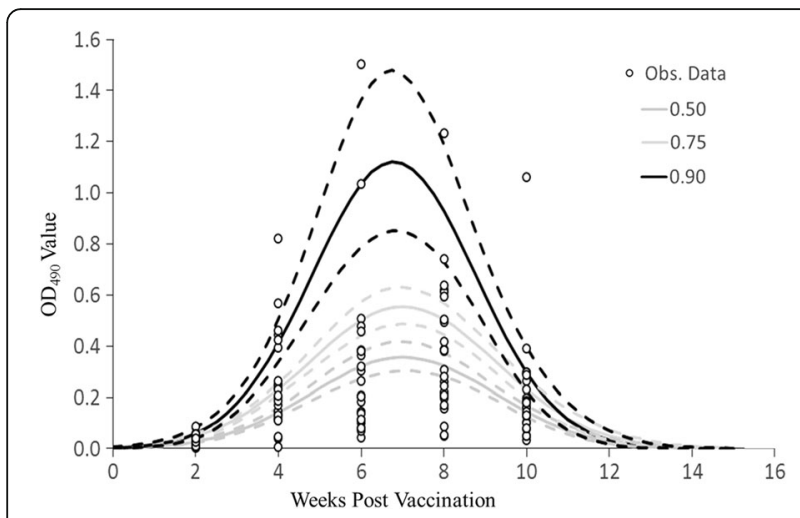

Fig. 1 Levels of anti-VHSV antibodies in immunized muskellunge. Levels of circulating anti-VHSV antibodies of 27 muskellunge for 10 weeks vaccinated with $10 \mu \mathrm{g}$ of the $\mathrm{PVHSivb}-\mathrm{G}$ indicated by indirect ELISA optical density $\left(\mathrm{OD}_{490}\right)$ values. The predicted relationships from $0.50,0.75$, and 0.90 quantile regression models was fit to the $\mathrm{OD}_{490}$ values as a function of time since vaccination. The dashed lines represent \pm 1 SE of the predicted relationships. The cut off value was estimated to be 0.163 , above which a sample was considered positive statistically significant $\left(0.50: \mathrm{x}^{2}=2.31, \mathrm{df}=1, P\right.$-value $=$ $0.128 ; 0.75: \mathrm{x}^{2}=2.01, \mathrm{df}=1, P$-value $=0.156 ; 0.90: \mathrm{x}^{2}=$ $0.57, \mathrm{df}=1, P$-value $=0.449$ ). Similarly, the square of time post-challenge was not statistically significant $(0.50$ : $\mathrm{x}^{2}=2.09, \mathrm{df}=1, P$-value $=0.148 ; 0.75: \mathrm{x}^{2}=2.17, \mathrm{df}=1, P$ value $=0.141 ; \quad 0.90: \quad x^{2}=1.44, \quad \mathrm{df}=1, \quad P$-value $\left.=0.231\right)$. Consequently, both terms were dropped from the models. Time post-challenge was statistically significant $(P$-value $<0.005)$ for all models. The fitted relationships for each of the quantile regression models was suggestive of an exponential decline in OD values with respect to time (Fig. 2, Table 3), however, this was likely influence by the lack of observations for the 4 weeks immediately following challenge. Based on the predicted relationships from the regression models, OD values would not be expected to decline to less than the establish positive/negative threshold (0.163) until between weeks 45 and 65 post challenge (Fig. 2).

\section{Viral shedding in pVHSivb-G vaccinated survivors}

Shedding was assessed in $\mathrm{pVHSivb-G}$ vaccinated survivors from MUS-2 beginning 16 weeks post challenge and MUS-3 beginning 4 weeks post challenge using a quantitative viral plaque assay. Low level of shedding

Table 3 Parameter estimates of quantile regression models fit to $\log _{e}$ OD values

\begin{tabular}{|c|c|c|c|c|}
\hline Quantile & Model output & Intercept & Time & Time $\times$ Time \\
\hline \multicolumn{5}{|c|}{ Post-Vaccination } \\
\hline \multirow[t]{3}{*}{0.5} & Estimate & -6.037 & 1.427 & -0.102 \\
\hline & standard error & 0.532 & 0.193 & 0.015 \\
\hline & 95\% confidence limits & -2.107 & $1.045-1.809$ & -0.059 \\
\hline \multirow[t]{3}{*}{0.75} & Estimate & -5.34 & 1.357 & -0.097 \\
\hline & standard error & 0.434 & 0.165 & 0.013 \\
\hline & 95\% confidence limits & -1.719 & $1.030-1.683$ & -0.052 \\
\hline \multirow[t]{3}{*}{0.9} & Estimate & -5.82 & 1.749 & -0.129 \\
\hline & standard error & 0.845 & 0.323 & 0.025 \\
\hline & 95\% confidence limits & -3.349 & $1.109-2.389$ & -0.1 \\
\hline \multicolumn{5}{|c|}{ Post-Challenge } \\
\hline \multirow[t]{3}{*}{0.5} & Estimate & 1.304 & -0.069 & NA \\
\hline & standard error & 0.187 & 0.103 & NA \\
\hline & 95\% confidence limits & $0.931-1.678$ & -0.041 & NA \\
\hline \multirow[t]{3}{*}{0.75} & Estimate & 1.343 & -0.048 & NA \\
\hline & standard error & 0.224 & 0.016 & NA \\
\hline & 95\% confidence limits & $0.896-1.791$ & -0.063 & NA \\
\hline \multirow[t]{3}{*}{0.9} & Estimate & 1.573 & -0.055 & NA \\
\hline & standard error & 0.317 & 0.021 & NA \\
\hline & 95\% confidence limits & $0.938-2.208$ & -0.085 & NA \\
\hline
\end{tabular}

Parameter estimates, standard errors, and 95\% confidence limits from $0.50,0.75$, and 0.90 quantile regression models fit to log ${ }_{e}$ OD values post pVHSivb-G immunization (Post Vaccination) and post VHSV challenge (Post Challenge). The fitted regression models for post-vaccination (PV) included weeks PV (Time) and the square of weeks PV (Time $\times$ Time) as explanatory variables. The fitted regression models for post-challenge included weeks post-challenge (Time) as an explanatory variable 


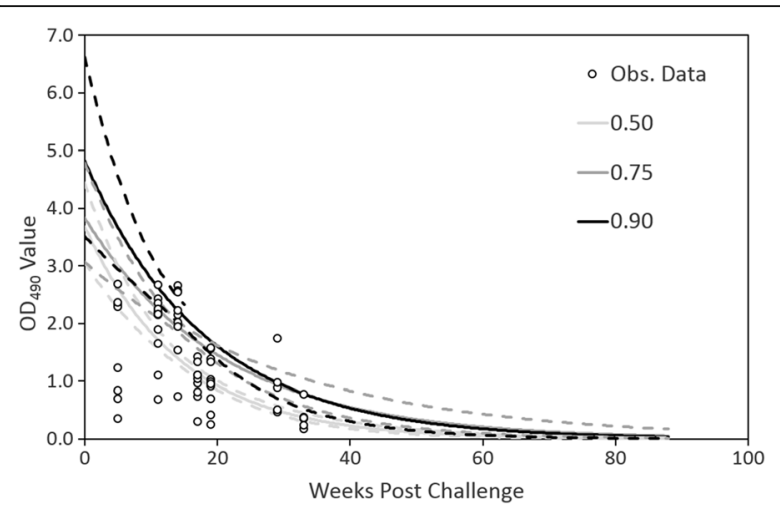

Fig. 2 Levels of anti-VHSV antibodies in immunized muskellunge following VHSV challenge. Levels of circulating anti-VHSV antibodies of 15 muskellunge following vaccinated with $10 \mu \mathrm{g}$ of the pVHSivb-G and VHSV immersion challenged $\left[\left(2 \times 10^{3} \mathrm{pfu} \mathrm{mL}^{-1}\right)\right.$ for $\left.60 \mathrm{~min}\right]$ indicated by indirect ELISA optical density $\left(\mathrm{OD}_{490}\right)$ values. Predicted relationships from $0.50,0.75$, and 0.90 quantile regression models fit to the $O D$ values as a function of time since vaccination. The dashed lines represent $\pm 1 \mathrm{SE}$ of the predicted relationships. The cut off value was estimated to be 0.163 , above which a sample was considered positive

was detected from a few survivors, with one fish at 4 and 20 weeks post challenge (Fig. 3), and two fish 8 weeks post challenge shedding $10^{4}$ to $2.0 \times 10^{4}$ pfu hour $^{-1}$. Two fish exhibited the maximum shedding concentration $\left(10^{5}\right.$ pfu hour $\left.^{-1}\right) 16$ weeks post challenge. No shedding was detected after 20 weeks post challenge from any individual. Overall, viral shedding from vaccinated survivors appears minimal and transient.

\section{Discussion}

Two decades of research have demonstrated that DNAbased vaccines can be highly effective for conferring protection against the European VHSV lineage (genotype Ia) in rainbow trout, a heavily cultured fish species [25-29]. Experimental DNA vaccine preparations have primarily incorporated the VHSV glycoprotein $(\mathrm{G})$ gene under the control of a human cytomegalovirus (CMV) promoter [15, 28-33]. The G gene is targeted as the encoded protein is necessity for VHSV attachment and cellular internalization [30, 34-36]. Studies show that IM administrations of doses ranging from $1 \mu \mathrm{g}[28,29]$ to $10 \mu \mathrm{g}$ [15] of a plasmid containing the VHSV glycoprotein $(\mathrm{G})$ gene, followed by an incubation period of $400-880^{\circ}$ days conferred $83-96 \%$ RPS in rainbow trout, when immersion challenged with $10^{4}$ to $3 \times 10^{6}$ median tissue culture infectious dose $\left(\mathrm{TCID}_{50}\right) \mathrm{mL}^{-1}[15,28,29]$. In our laboratory, when this protocol was used in muskellunge it did not protect over half of vaccinated fish upon challenge [10] and therefore this study was designed. When we increased the period that vaccinated muskellunge had to mount an immune response prior to challenge, this resulted in greater survivorship than the $45 \%$ RPS previously demonstrated. It seems that a longer time post-vaccination is needed to provide fish sufficient time to develop a protective immune response [37]. The fact that vaccinated fish need a relatively long time to develop a protective response dictates that the vaccine should be administered in their early life stages so that they are protected prior to their stocking in public waters. In muskellunge, the highest RPS (100\%)

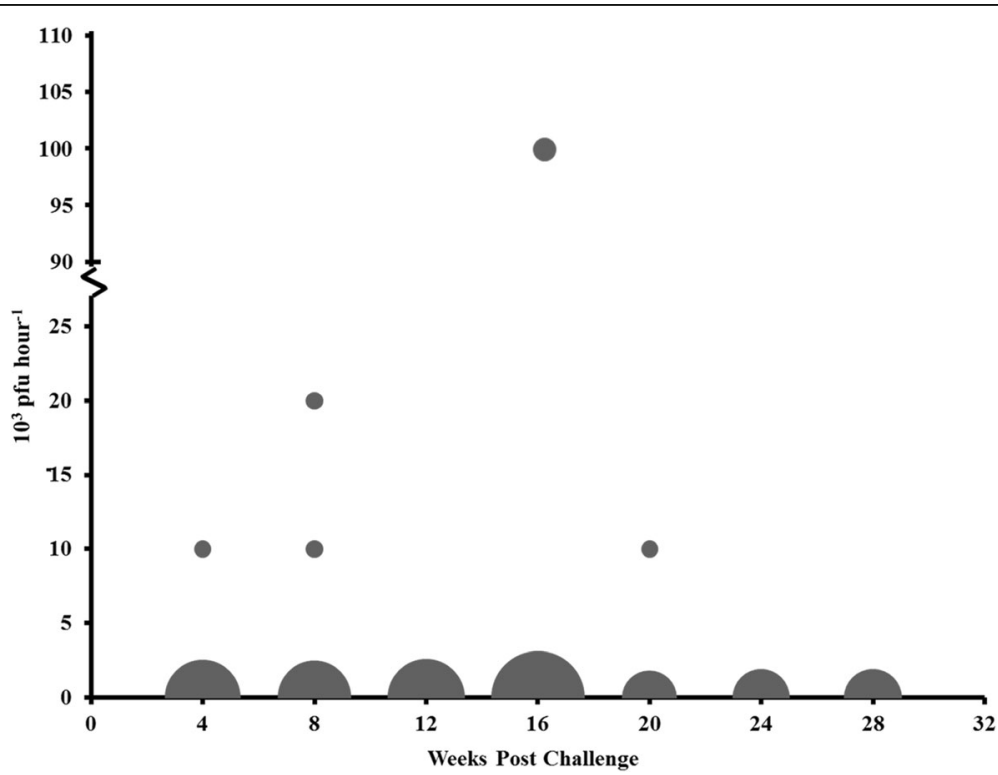

Fig. 3 VHSV shedding in immunized muskellunge following shedding. Weighted bubble graph displaying the analysis of shedding in pVHSivb-G vaccinated muskellunge $(n=39)$ following a VHSV-IVb immersion challenge $\left(2 \times 10^{3} \mathrm{pfu} \mathrm{mL}^{-1}\right.$ for $\left.60 \mathrm{~min}\right)$. Viral plaque assays were conducted on water samples collected from individual surviving muskellunge every 4 weeks until 28 weeks post challenge 
was observed in MUS-3 when muskellunge received two administrations of the pVHSivb-G preparation, though a single administration in MUS-2 under otherwise similar conditions also resulted in a high RPS (95\% RPS). It seems that administration of more than vaccine dose is not necessary to achieve protection.

In salmonids, we also demonstrated significant protection in each species following IP challenge, with RPS ranging from 27.8 to $100 \%$ in these trials. The $100 \%$ RPS observed in both the lake trout trials is comparable to the protection previously achieved with DNA preparations against VHSV-I and a similar novirhabdovirus, IHNV in rainbow trout $[15,29]$. Though, salmonids are less susceptible to genotype IVb, and a high IP viral concentration was required to elicit mortality and demonstrate protection. If environmentally realistic concentrations were utilized [38], this would likely result in greater protection and survivorship then we have documented. RPS varied based on the administration of either one or two doses of the pVHSivb-G plasmid; in BNT-1, fish actually experienced greater protection following only one administration of the plasmid. Also lake trout experienced identical protection regardless of the number of plasmid administrations, providing further evidence that a single administration of the plasmid elicits sufficient protection.

We further demonstrate several novel aspects of post vaccine efficacy. For example, the indirect ELISA demonstrates that the pVHSivb-G plasmid elicited the development of a significant circulating VHSV-binding antibody response in muskellunge, which peaked around 7 weeks post vaccination. Though, in muskellunge from the previous study by Millard et al. [10], 7 weeks post vaccination corresponded with the initial development of a neutralizing antibody response, with only 1 of 12 vaccinated muskellunge exhibiting neutralizing anti-VHSV antibodies, though, 4 weeks later $60 \%$ of muskellunge exhibited neutralizing antibodies [10]. This discrepancy can be attributed to the fact the used indirect ELISA employed in this study detects all binding antibodies generated in response to the vaccine while neutralization antibody assay measure only one subset of these antibodies. Though, in this study, the incubation period and subsequent challenge we utilized with muskellunge did not appear to correspond with peak anti-VHSV binding antibody levels as indicated by the ELISA OD values. Peak binding antibodies levels may not correspond with peak protection; however, the magnitude of the humoral response does appear to indicate the development of an adaptive response and involving long lived plasma cells (LLPC) [39]. In studies done on rainbow trout using a non-microbial antigen, it has been demonstrated that antibodies produced 12-15 weeks following immunization have a much higher affinity to the antigen [40]. A similar phenomenon may be taking place in muskellunge thus explaining the significant protection despite the overall declining antibody levels. Further, in vaccinated muskellunge, following challenge, we were able to detect a vigorous secondary response. We were able to predict this response would to remain at detectable levels for upwards of 40-50 weeks and is suggestive a prolonged secondary immune response. The details of the kinetics of the primary and secondary humoral response provide a valuable input for future vaccination and release strategies if this preparation is approved for use in aquaculture. Needless to say, cell mediated immunity may also play a major role in protection of vaccinated fish and should be investigated in future studies.

The finding that some vaccinated muskellunge, while protected, may also shed VHSV-IVb into the water column following exposure is troublesome, however, shedding was restricted to a small subset of vaccinated fish that survived the challenge with a relative high virus dose. In the aquatic environment, it is highly unlikely that fish will be exposed to this viral concentration even in VHSV endemic waters [38]. In general, VHSV shedding in fish surviving experimental challenge is of a transient nature [21]. Our data similarly reflects this trend, however, determination and kinetics of shedding kinetics in vaccinated and challenged fish should be ascertained. Unfortunately, all other studies that described vaccine development against VHSV never addressed shedding as a measure of post-challenge vaccine evaluation [10, 15, 16, 26-29].

Herein we have demonstrated that the pVHSivb-G plasmid can elicit significant protection against VHSV$\mathrm{IVb}$ in several species. Though salmonids are less susceptible to genotype IVb, obtaining a protective vaccine will provide researchers and managers with a potent tool that can be used to limit transmission of VHSV-IVb. Most recently, we provided evidence that vaccinated muskellunge can significantly minimize mortalities in cohabitating naïve fish upon experimental challenge, a phenomenon which mimics the concept of herd immunity in terrestrial animals [20]. By vaccinating the millions of propagated salmonid fry and fingerlings prior to stocking, the Great Lakes hatchery system could be used to elicit a large-scale "herd immunity" response. With an overall decrease in the number of naïve-susceptible individuals being stocked, there would be a corresponding decreased viral transmission and an indirect protective effect to other naïve individuals.

\section{Conclusions}

In conclusion, the results we have obtained and the vaccination model we have developed can be used as a first step toward providing managers with tool to stop VHSV dissemination and associated losses. Additionally, the development of an efficacious vaccine preparation allows us to more thoroughly study the nature of immune response in teleosts against serious pathogens. 


\section{Additional files}

Additional file 1: Cumulative mortality data for vaccination trials of muskellunge and three salmonid species. (XLSX 14 kb)

Additional file 2: Anti-VHSV antibody level in immunized muskellunge pre and post VHSV-IVb challenge. (XLSX $12 \mathrm{~kb})$

\section{Abbreviations}

BNT-1, 2: Brown trout trials; CMV: Cytomegalovirus promoter; IM: Intramuscular; IP: Intraperitoneal; LAT-1, 2: Lake trout trials; MUS-1, 2, 3: Muskellunge trials; OD: Optical density; PV: Post-vaccination; pVHSivb-G: DNA plasmid containing VHSV-IVb glycoprotein gene; RBT-1,2: Rainbow trout trials; RPS: Relative percent survival; RT-qPCR: Quantitative reverse transcription polymerase chain reaction; VPA: Viral plaque assay

\section{Acknowledgements}

We thank the Michigan Department of Natural Resources and the New York Department of Environmental Conservation for supplying fish for the study.

\section{Funding}

The Great Lakes Fishery Trust (Grant \# 2012.1257) funded this research. The funding agency did not play a role in the study design, data collection or analysis, or manuscript preparation.

\section{Availability of data and materials}

Supporting data can be found in the supplementary documents, titled Additional files 1 and 2 .

\section{Authors' contributions}

EM designed the plasmid. IS and MF designed and implemented the study. IS performed the study and collected samples. IS and TB performed statistical analyses. IS, EM, TB and MF drafted and revised the manuscript. All authors have read and approved the final manuscript.

\section{Competing interests}

The authors declare that they have no competing interests.

\section{Consent for publication}

Not applicable.

\section{Received: 6 May 2016 Accepted: 29 November 2016} Published online: 02 December 2016

\section{References}

1. Elsayed E, Faisal M, Thomas M, Whelan G, Batts W, Winton J. Isolation of viral haemorrhagic septicaemia virus from muskellunge, Esox masquinongy (Mitchill), in Lake St. Clair, Michigan, USA reveals a new sublineage of the North American genotype. J Fish Dis. 2006;29:611-9.

2. Faisal M, Shavalier M, Kim RK, Millard EV, Gunn MR, Winters AD, Schulz CA Eissa A, Thomas MV, Wolgamood M, Whelan GE, Winton J. Spread of the Emerging Viral Hemorrhagic Septicemia Virus Strain, Genotype IVb, in Michigan. USA Viruses. 2012;4:734-60.

3. Animal and Plant Health Inspection Service. Viral hemorrhagic Septicemia Virus IVb. U.S Department of Agriculture. U.S. Surveillance Report. 2009.

4. Kim R, Faisal M. Experimental studies confirm the wide host range of the Great Lakes viral haemorrhagic speticaemia virus genotype IVb. J Fish Dis. 2010;33:83-8.

5. Kim R, Faisal M. Comparative susceptibility of representative Great Lakes fish species to the North American viral hemorrhagic septicemia virus sublineage IVb. Dis Aquat Organ. 2010;91:23-34.

6. Kim RK, Faisal M. The Laurentian Great Lakes strain (MI03) of the viral hemorrohagic septicemia is highly pathogenic for juvenile muskellunge, Esox masquinongy (Mitchill). J Fish Dis. 2010;33:513-27.

7. Miller RR. Threatened freshwater fishes of the United States. Trans Am Fish Soc. 1972:101(2):239-52.

8. Dexter $\lrcorner$, O'Neal RP. Michigan fish stocking guidelines II: with periodic updates. Michigan Department of Natural Resources Fisheries Division Special Report 32. 2004. p. 68

9. Faisal M, Schulz CA, Loch TP, Kim RK, Hnath J, Whelan G. Current Status of Fish Health and Disease Issues in the Laurentian Great Lakes: 2005-2010. In:
Great Lakes fisheries policy and management: a binational perspective. East Lansing: Michigan State University Press; 2013. p. 259-302.

10. Millard, EV, LaPatra, SE, Brenden, TO, Bourke, AM, Fitzgerald, SD, Faisal, M. DNA vaccination partially protects muskellunge Esox masquinongy against viral hemorrhagic septicemia virus (VHSV-IVb). J Aquat Anim Health In press

11. Office International des Eptizooties. Manual of Diagnostic Tests for Aquatic Animals. 6th ed. Paris: World Animal Health Organization; 2009.

12. American Fisheries Society-Fish Health Section. FHS Blue book: suggested procedures for the detection and identification of certain finfish and shellfish pathogens. Bethesda: AFS-FHS; 2012.

13. Batts WN, Winton JR. Enhanced detection of infectious hematopoietic necrosis virus and other fish viruses by pretreatment of cell monolayers with polyethylene glycol. J Aquat Anim Health. 1989;1:284-90.

14. Batts WN, Traxler GS, Winton JR. Factors affecting the efficiency of plating for selected fish rhabdoviruses. In: Proceedings of the second International Symposium on Viruses of Lower Vertebrates. Corvallis: Oregon State University Press; 1991. p. 17-24.

15. Lorenzen N, Lorenzen E, Einer-Jensen K, Heppell J, Wu T, Davis H. Protective immunity to VHS in rainbow trout following DNA vaccination. Fish Shellfish Immunol. 1998;8:261-70.

16. Heppell J, Lorenzen N, Armstrong NK, Wu T, Lorenzen E, Einer-Jensen K, Schorr J, Davis H. Development of DNA vaccines for fish: Vector design, intramuscular injection and antigen expression using viral haemorrhagic septicaemia virus genes as model. Fish Shellfish Immunol. 1998:8:271-86.

17. Anderson ED, Mourich DV, Fahrenkrug SC, LaPatra S, Shepherd J, Leong JA. Genetic immunization of rainbow trout (Oncorhynchus mykiss) against infectious hematopoietic necrosis virus. Mol Mar Biol Biotechnol. 1996;5:114-22.

18. Jonstrup SP, Kahns S, Skall HF, Boutrup TS, Olesen NJ. Development and validation of a novel taqman-based real-time RT-PCR assay suitable for demonstrating freedom from viral haemorrhagic septicaemia virus. J Fish Dis. 2013;36:9-23.

19. Warg JV, Clement T, Cornwell ER, Cruz A, Getchell RG, Giray C, Goodwin AE, Groocock GH, Faisal M, Kim R, Merry GE, Phelps ND, Reising MM, Standish I, Zhang Y, Toohey-Kurth K. Comparison of four real-time RT-PCR protocols for the detection and surveillance of viral hemorrhagic septicemia virus in the framework of a USA laboratory network. Dis Aquat Organ. 2014:111:1-13.

20. Standish IF. Eliciting protection and herd immunity in fish against viral hemorrhagic septicemia virus genotype IVb. PhD Dissertation. East Lansing: Michigan State University; 2016. p. 225.

21. Kim R, Faisal M. Shedding of viral hemorrhagic septicemia virus (Genotype IVb) by experimentally infected muskellunge (Esox masquinongy). J Microbio. 2012;50:278-84.

22. SAS Institute. SAS/STAT ${ }^{\oplus} 9.22$ User's guide. Cary: SAS Institute; 2010.

23. Amend DF. Potency testing of fish vaccines. Dev Biol Stand. 1981;49:447-54

24. Cade BS, Noon BR. A gentle introduction to quantile regression for ecologists. Front Ecol Environ. 2003;1:412-20.

25. Kurath G. Overview of recent DNA vaccine development for fish. Dev Biol. 2005;121:201-13.

26. De Kinkelin $\mathrm{P}$, Bearzotti-Le M. Immunization of rainbow trout against viral hemorrhagic septicemia with a thermoresistant variant of the virus. Dev Biol Stand. 1981:49:431-9.

27. Boudinot P, Blanco M, De Kinkelin P, Benmansour A. Combined DNA immunization with the glycoprotein gene of viral hemorrhagic septicemia virus and infectious hematopoietic necrosis virus induces double-specific protective immunity and nonspecific response in rainbow trout. Virology. 1998:249:297-306

28. Chico V, Ortega-Villaizan M, Falco A, Tafallo C, Perez L, Coll JM, Estepa A. The immunogenicity of viral hemorrhagic speticaemia rhabdovirus (VHSV) DNA vaccines can depend on plasmid regulatory sequences. Vaccine. 2009; 27:1938-48.

29. Einer-Jensen K, Delgabo L, Lorenzen E, Bovo G, Evensen O, LaPatra S, Lorenzen $N$. Dual DNA vaccination of rainbow trout against two different rhabdoviruses, VHSV and IHNV, induces specific divalent protection. Vaccine. 2009;27:1248-53.

30. Lorenzen N, Olesen NJ, Jørgensen PEV. Neutralization of Egtved virus pathogenicity to cell cultures and fish by monoclonal antibodies to the viral G protein. J Gen Virol. 1990;71:561-7.

31. Lorenzen $\mathrm{N}$, Olesen NJ, Koch C. Immunity to VHS virus in rainbow trout. Aquaculture 1999:172:41-61.

32. Lorenzen $\mathrm{N}$, Lorenzen $\mathrm{E}$, Einer-Jensen K. Immunity to viral haemorrhagic septicaemia (VHS) following DNA vaccination of rainbow trout at an early life stage. Fish Shellfish Immunol. 2001;11:585-91. 
33. Hart LM, Lorenzen N, LaPatra SE, Grady A, Roon SE, O'Reilly J, Gregg JL, Hershberger PK. Efficacy of a glycoprotein DNA vaccine against viral haemorrhagic speticaemia (VHS) in pacific herring, Clupea pallasii Valenciennes. J Fish Dis. 2012;35:775-9.

34. Bearzotti M, Monnier AF, Vende P, Grosclaude J, De Kinkelin P, Benmansour A. The glycoprotein of viral hemorrhagic septicemia virus (VHSV): antigenicity and role in virulence. J Vet Res. 1995;26:413-22.

35. Lorenzen N, LaPatra SE. Immunity to rhabdoviruses in rainbow trout: the antibody response. Fish Shellfish Immunol. 1999;9:345-60.

36. Einer-Jensen $K$, Ahrens $P$, Forsberg $R$, Lorenzen $N$. Evolution of the fish rhabdovirus viral haemorrhagic septicaemia virus. J Gen Virol. 2004:85:1167-79.

37. Le Morvan C, Troutaud D, Deschaux P. Differential effects of temperature on specific and nonspecific immune defences in fish. J Exp Biol. 1998;201:165-8.

38. Bain MB, Cornwell ER, Hope KM, Eckerlin GE, Casey RN, Groocock GH, Getchell RG, Bowser PR, Winton JR, Batts WN, Cangelosi A, Casey JW. Distribution of an invasive aquatic pathogen (viral hemorrhagic septicemia virus) in the Great Lakes and its relationship to shipping. PLOS ONE. 2010;5: e10156.

39. Ye J, Bromage ES, Kaattari SL. The strength of B cell interaction with antigen determines the degree of IgM polymerization. J Immunol. 2009;184:844-50.

40. Ye J, Kaattari I, Kaattari SL. Plasmablasts and plasma cells: Reconsidering teleost immune system organization. Dev Comp Immunol. 2011;35:1273-81.

\section{Submit your next manuscript to BioMed Central} and we will help you at every step:

- We accept pre-submission inquiries

- Our selector tool helps you to find the most relevant journal

- We provide round the clock customer support

- Convenient online submission

- Thorough peer review

- Inclusion in PubMed and all major indexing services

- Maximum visibility for your research

Submit your manuscript at www.biomedcentral.com/submit 